\title{
Design Learning Environment Based on ISTE Standards
}

Magdy S. Aqel, Islamic University of Gaza, Palestine

\begin{abstract}
The study aimed to design a learning environment based on ISTE standards for students and computer science educators. For answering the questions of the study, the researchers adopted the descriptive approach. They identified the ISTE standards and analyzed the content of instructional technology course based on ISTE standards for students and for computer science educators. Then they designed learning environment based on this standard. The sample of the study consists of all students enrolled for an instructional technology course at the first semester 2017 in faculty of education in the Islamic University; the tool of the study was a content analysis to analyze and design the learning environment based on ISTE standards. The study recommended integrating ISTE standards in academic preparation programs for teachers of faculty of education and holding training courses for students and teachers in universities to introduce ISTE standards and motivate teachers and students to embrace these standards.
\end{abstract}

\section{KEYWORDS}

ISTE, Learning Environment

\section{INTRODUCTION}

In the early twentieth century, film and radio were the initial technology additions to the classroom. They were both passive ways of teaching students. Sitting and watching a screen or listening to someone speaking over a radio was no different than having a teacher teaching in the room. In fact, it was worse because there was not an opportunity to interrupt and ask questions, and the transmission may have been difficult to hear or understand. The invention of the computer created an active environment for one user and could connect users to information, but the additions of computers and televisions to classrooms were used as accessories rather than active tools for learning. Even after the invention of the internet and its establishment in schools, it is difficult find an active and collaborative environment that doesn't directly reflect the traditional and passive ways of teaching, Small and portable electronics allow students to use self-guided programs to become more independent learners. Instead of the reliance of physically being connected to the teacher to learn, there is the chance to connect and learn digitally and thus freeing students from the traditional classroom. (Moehring, 2012).

Everyone needs a stimulating environment and connections with others to develop new ideas, strategies and knowledge.

So it's the time for major change in education is now. In a world where rapid advances in technology have a profound impact on the ways we work, communicate and live, education 
has struggled to keep pace. The ISTE Standards work together to support educators, students and leaders with clear guidelines for the skills and knowledge necessary to move away from the factory model. These are not the typical boxes educators need to check. They provide a framework for rethinking education, adapting to a constantly changing technological landscape and preparing students to enter an increasingly global economy. (www.iste.org, 2017).

Students today need access to the digital tools and media-rich resources that will help them explore, understand, and express themselves in the world they will inherit tomorrow. Educators need access to tools and resources to share knowledge and practice with other professionals, interact with experts in their field, and connect with their students" families and communities. (21st Century Curriculum and Instruction)

The best way to learn is to connect with other educators at face-to-face conferences, such as the ISTE Conference \& Expo, or within online communities. These are great places to learn at the school, regional, national or international level about ways to use new technologies to extend and enhance student learning. They are also where educators can share their knowledge with others and contribute to the effectiveness, vitality and self-renewal of their profession. (Crompton, 2014)

In this research a design learning environment model which consists of five phases is proposed based on ISTE standards for students and for educators. The five phases of the ADDIE Model are: Analysis, Design, Development, Implementation, and Evaluation.

\section{Problem Statement}

The main problem in this research is how to design learning environment which supports ISTE standards for students \& computer science educators.

\section{Objectives of Study}

1. Identify the ISTE standards 2017, its conditions and activities.

2. Design learning environment based on ISTE standard.

\section{Theoretical Framework}

The ISTE Standards consist of five sets of standards and provide a framework for amplifying or even transforming digital age learning, teaching and leading.

\section{The ISTE Standards}

ISTE Standards for Students $(2016,2007)$

ISTE Standards for Teachers

ISTE Standards for Administrators

ISTE Standards for Coaches

ISTE Standards for Computer Science Educators

The ISTE Standards are designed to serve the field for 5-10 years as a blueprint for tech adoption and implementation. But education technology moves quickly, so the ISTE Standards must be refreshed periodically to reflect the current and coming state of education. In 2016, ISTE updated the ISTE Standards for Students and began a refresh of the ISTE Standards for Teachers, which will be released in 2017. The administrator, coach and computer science educator standards will be updated in the coming years. 


\section{LEARNING ENVIRONMENT}

Learning environment refers to the diverse physical locations, contexts, and cultures in which students learn. Since students may learn in a wide variety of settings, such as outside-of-school locations and outdoor environments, the term is often used as a more accurate or preferred alternative to classroom, which has more limited and traditional connotations a room with rows of desks and a chalkboard, for example.

The term also encompasses the culture of a school or class its presiding ethos and characteristics, including how individuals interact with and treat one another as well as the ways in which teachers may organize an educational setting to facilitate learning e.g., by conducting classes in relevant natural ecosystems, grouping desks in specific ways, decorating the walls with learning materials, or utilizing audio, visual, and digital technologies. And because the qualities and characteristics of a learning environment are determined by a wide variety of factors, school policies, governance structures, and other features may also be considered elements of a "learning environment." Educators may also argue that learning environments have both a direct and indirect influence on student learning, including their engagement in what is being taught, their motivation to learn, and their sense of well-being, belonging, and personal safety. (Glossary, 2013).

Wherefore the researchers decided to design positive learning environment to motivate the students to learn and allows students to feel comfortable and confident.

\section{INSTRUCTIONAL DESIGN}

What is instructional design?

ID may be defined as using a systematic approach to solve an instructional problem. The ID process begins by identifying the performance problem of learners and then determines if instruction is the appropriate solution. Solutions to an instructional problem incorporate the use of technology and learning theories. The systematic approach consists of instructional system design (ISD) models, such as ADDIE, ASSURE, and the Dick and Carey model. (Davis, 2013)

Types of web -based learning experiences (O’Neil \&Perez, 2013):

1. Formal course or module of distance learning_ goal focused and wholly delivered through a distributed network. Place and time of instruction partially unconstrained.

2. Blended course _ goal focused, core instructional delivery and interactions is shared by live and computer-supported instruction. Some synchronous instruction required.

3. Technology-supported courses _ course materials, assignments, chat and other features are available to augment a traditional live teacher, but the balance is on live instruction.

4. Technology-enriched environments practice opportunities or simulations particularly for subtasks are provided by the web. Most instruction is live.

5. Discretionary web activity enrichment or other activities supporting computer literacy skills.

6. Tools use learning that occurs related to the use of interactive tools involving search, document preparation, and spreadsheet and database design and collaborative work.

7. Focused games and simulations goal focused or goal emergent with a set of learning expectations including content, strategy, and persistence.

8. Exploratory games and simulations goals focused, emergent, and unpredictable learnings occur; procedures, constraints, and processes.

9. Domain specific incidental learning relevant to learning rules and rewards of using (usually) commercial sites. 


\section{IT and Computer in School Design}

"Even when conservative estimates suggest that current classrooms where students are currently learning have not changed in decades, is it likely that today's classroom format is appropriate for the tasks they are supposed to do in modern society?

IT and computers are used throughout the modern society, changing the way people work and live. People are constantly connected with each other around the world through technology during most waking hours. "It stands out in every aspect of our social, cultural, psychological and working environment." 35 The way in which schools are traditionally organized prohibits this inevitable pattern of technology. ICT adapts to classrooms rather than reflecting our dedicated use today. Our school's designs have not changed physically to adapt to changes that are currently occurring outside the classroom. How can we expect our children to meet today's expectations and to be tomorrow's leaders when they learn in traditional environments built for a particular kind of education and curriculum more than a hundred years ago?

The desire to change education in schools and classrooms is a common view among teachers. They want students to master the multidimensional abilities that will be required to compete and lead the global economy. It is seen that if we cannot adapt to these new changes, our children will be left behind. An example of this ambition is Partnership for 21st Century Skills (Figure 1). Its framework reflects the desire to develop skills including collaboration, innovation and technology skills along with supportive approaches and the environment. (Moehring, 2012).

\section{METHODOLOGY}

The researchers followed the descriptive approach, where they analyzed the content of Instructional technology course based on ISTE standards, the analysis was done using ADDIE model.

Figure 1. An example of Partnership for 21st Century Skills

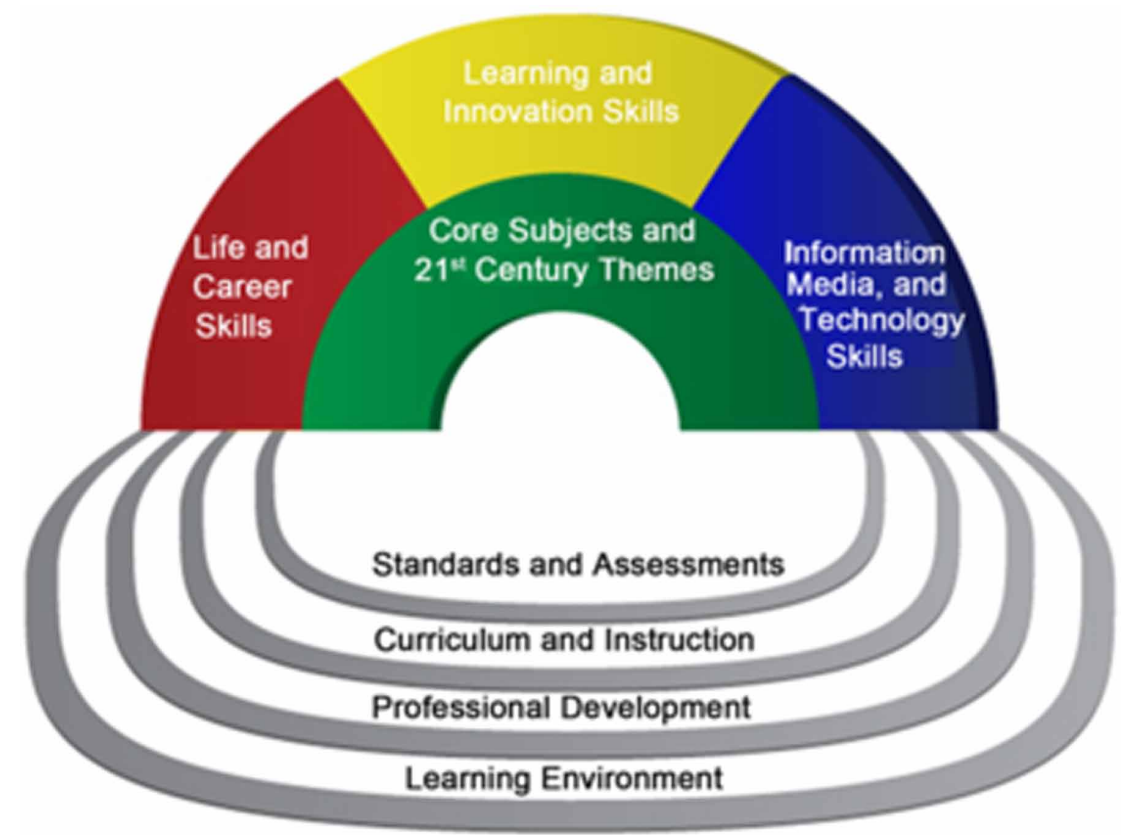




\section{The ADDIE Model}

There are more than 100 different instructional system design models, but almost all are based on the generic "ADDIE" model, which stands for Analysis, Design, Development, Implementation, and Evaluation, as illustrated in Figure 1. Each step has an outcome that feeds the subsequent step. Analysis, Design, Development, Implementation, Evaluation. During analysis, the designer develops a clear understanding of the "gaps" between the desired outcomes or behaviors, and the audience's existing knowledge and skills. The design phase documents specific learning objectives, assessment instruments, exercises, and content. The actual creation of learning materials is completed in the development phase. During implementation, these materials are delivered or distributed to the student group. After delivery, the effectiveness of the training materials is evaluated (Kruse, 2002).

Morrison (2010) defines ADDIE is an instructional systems design (ISD) framework that many instructional designers and training developers use to develop courses. The name is initialism for the five phases it defines for building training and performance support tools:

1. Analysis

2. Design

3. Development

4. Implementation

5. Evaluation.

\section{Analysis Phase}

This is the first step in ADDIE model; where the instructional problem is identified along with learner characteristics, and learning objectives is determined, in this phase the researchers done the following steps:

1. Defining the ISTE standards 2016, and defining standards for educators and students.

2. Defining the learning objectives and skills necessary, the researchers adopted the google site skills to design the learning environment.

3. Analysis the content of instructional technology-practical course based on ISTE standards.

\section{Design Phase}

This is the second step in ADDIE model, where an outline of instructional strategies is created and learning activities and assessment are determined. In this phase, the researchers designed the learning environment based on ISTE standards, as shown below.

\section{Development Phase}

This is the third step in ADDIE model, in this phase we are going to build our learning content, learning assignments, and assessment. We will also need to identify which technologies should be chosen to enhance our learning experience.

\section{Implementation Phase}

This is the fourth step in ADDIE model, the implementation phase includes the testing of prototypes where training for the instructor happens followed by learners participating in the instruction.

\section{Evaluation Phase}

This is the last step in ADDIE model, assessment of program intended to ensure the training and content achieved the learning objectives, Evaluation consists of two parts: formative and summative. 
Table 1. ISTE Standards for Students

\begin{tabular}{|c|c|c|c|c|}
\hline \# & Standard & Skill & Activity & The used tool \\
\hline 1. & Empowered learner & $\begin{array}{l}\text { - Create and use Gmail } \\
\text { account. }\end{array}$ & $\begin{array}{l}\text {-The learner creates his } \\
\text { own E- mail. } \\
\text { Gmail }\end{array}$ & $\begin{array}{l}\text { A website that } \\
\text { explains the steps to } \\
\text { create a Gmail. }\end{array}$ \\
\hline \multirow[t]{3}{*}{2.} & \multirow[t]{3}{*}{ Digital Citizen } & \multirow[t]{3}{*}{$\begin{array}{l}\text { - Dealing with E- } \\
\text { mail } \\
\text {-Learn about } \\
\text { Google Apps. } \\
\text {-Search and } \\
\text { browse the web }\end{array}$} & $\begin{array}{l}\text {-The learner opens his E- } \\
\text { mail, send and receive E- } \\
\text { mails and upload and } \\
\text { download files. } \\
\text {-The student knows that } \\
\text { Gmail is the key login } \\
\text { for all Google } \\
\text { applications and some } \\
\text { applications that could } \\
\text { be useful for him in the } \\
\text { education process } \\
\text { including (Google Drive, } \\
\text { google sites, YouTube, } \\
\text { Hangouts ...) } \\
\text { fongle }\end{array}$ & \multirow[t]{3}{*}{$\begin{array}{l}\text { Videos from } \\
\text { different websites }\end{array}$} \\
\hline & & & $\begin{array}{l}\text {-Looking for using } \\
\text { different search engines } \\
\text { to upload and download } \\
\text { files from and to a } \\
\text { computer. }\end{array}$ & \\
\hline & & & 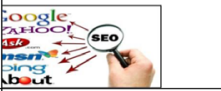 & \\
\hline 3. & $\begin{array}{l}\text { Knowledge } \\
\text { Constructor }\end{array}$ & $\begin{array}{l}\text { - Produces its } \\
\text { own site on } \\
\text { google site. } \\
\text {-Creates various } \\
\text { pages on Google } \\
\text { Site } \\
\text {-Format pages }\end{array}$ & $\begin{array}{l}\text {-The learner creates their } \\
\text { own site on Google site, } \\
\text { by following the steps } \\
\text { explained in educational } \\
\text { videos and then designs } \\
\text { a variety of pages within } \\
\text { the site as type (Web, } \\
\text { announcements, list, and }\end{array}$ & $\begin{array}{l}\text { Educational videos } \\
\text { are previously } \\
\text { Prepared available } \\
\text { on YouTube And } \\
\text { on the Islamic } \\
\text { University Moodle } \\
\text { site. }\end{array}$ \\
\hline
\end{tabular}

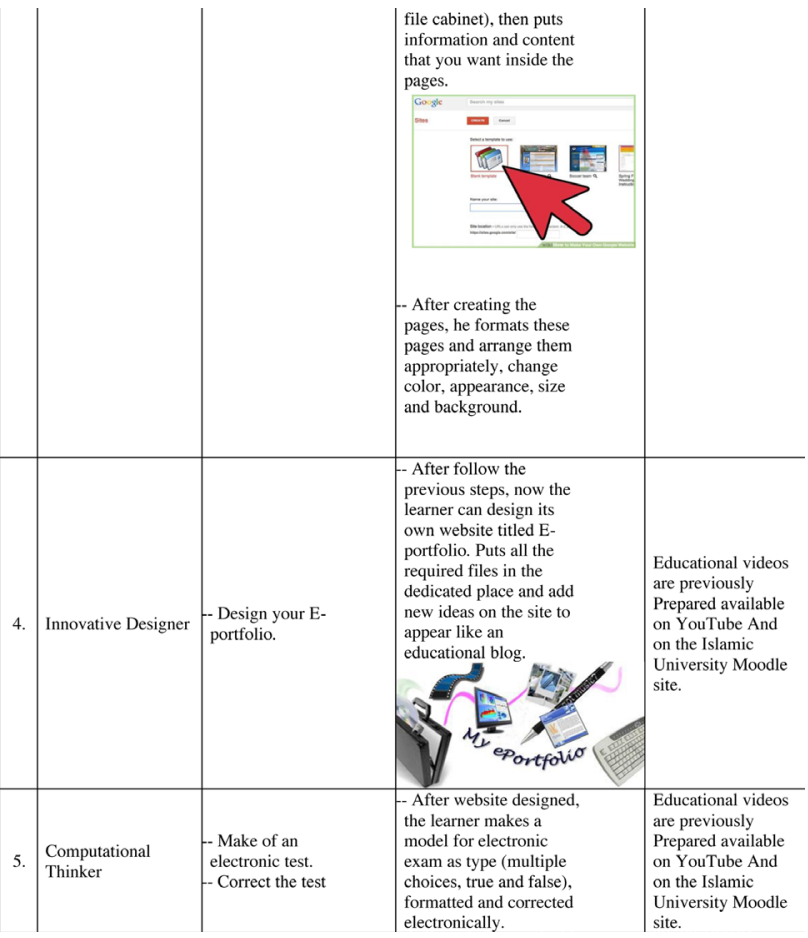


Table 1. Continued

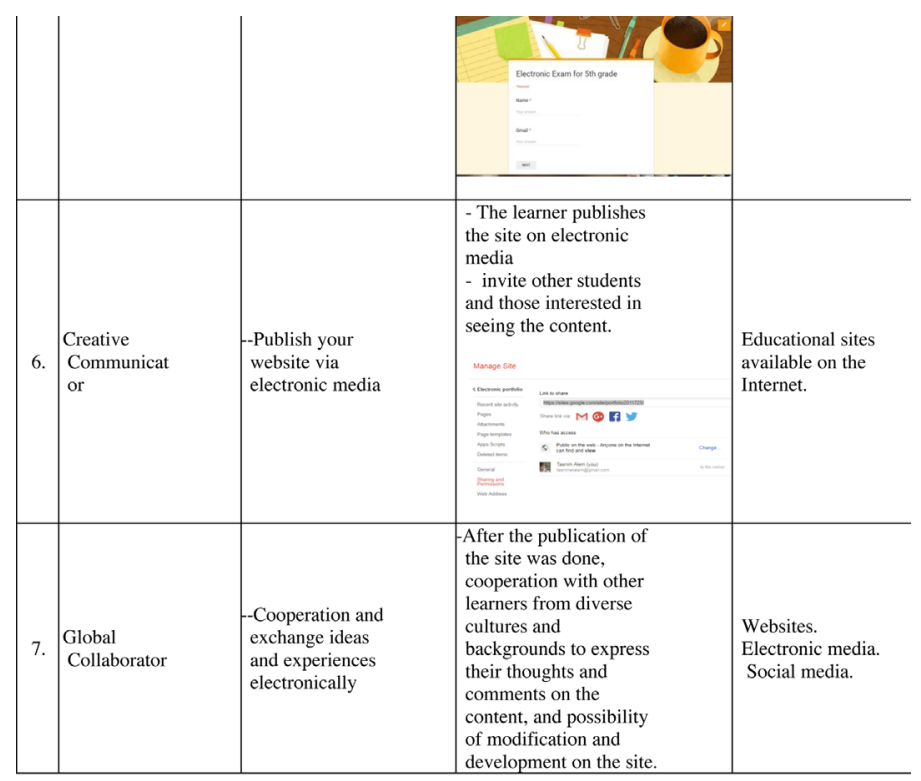

Table 2. ISTE standard for computer science educator

\begin{tabular}{|c|c|c|c|c|}
\hline & Standard & skill & activity & $\begin{array}{l}\text { The used } \\
\text { tool }\end{array}$ \\
\hline 1 & $\begin{array}{l}\text { Knowledge of } \\
\text { content }\end{array}$ & $\begin{array}{l}\text { All google site } \\
\text { skills }\end{array}$ & $\begin{array}{l}\text {-The science educator knows the } \\
\text { content to be taught and understands } \\
\text { well } \\
\text { For example: teach the student's E- } \\
\text { content design skills using Google } \\
\text { site, } \\
\text {-the educator must know and } \\
\text { understand all the required skills } \\
\text { and start a good planning to the } \\
\text { lesson and prepare teaching digital } \\
\text { aids and identify the appropriate } \\
\text { strategies, and identify assessment } \\
\text { methods. }\end{array}$ & $\begin{array}{l}\text { Educational } \\
\text { sites }\end{array}$ \\
\hline 2 & $\begin{array}{l}\text { Effective } \\
\text { teaching and } \\
\text { learning } \\
\text { strategies }\end{array}$ & $\begin{array}{l}\text { All google site } \\
\text { skills }\end{array}$ & $\begin{array}{l}\text {-The educator use new strategies } \\
\text { within active learning that based on } \\
\text { internet like flipped class room } \\
\text { strategy. } \\
\text {-for example the teacher want to } \\
\text { explain website design skills, the } \\
\text { steps is: } \\
\text { 1- Designs educational videos to } \\
\text { explain all Google website skills. } \\
\text { 2- Up load the videos on YouTube } \\
\text { site. }\end{array}$ & $\begin{array}{l}\text { - Camta } \\
\text { sia } \\
\text { progra } \\
\text { m to } \\
\text { design } \\
\text { the } \\
\text { videos } \\
\text {. } \\
\text { You } \\
\text { tube } \\
\text { site. }\end{array}$ \\
\hline & & & Eos & 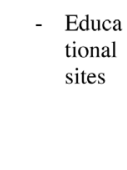 \\
\hline
\end{tabular}


Table 2. Continued

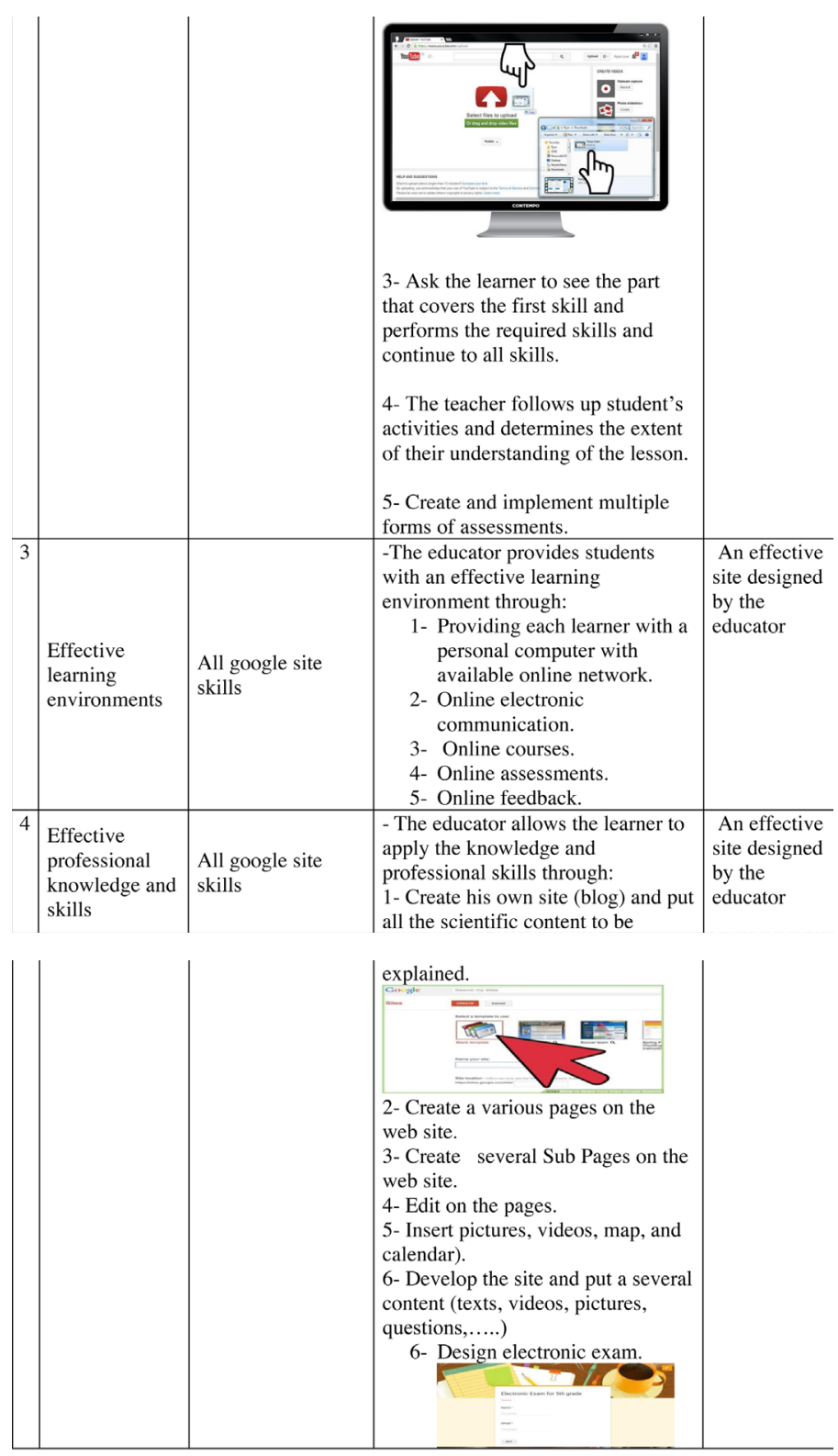

Formative evaluation is a measurement of learning outcomes during the instruction process, and summative evaluation measurement of learning outcomes after instruction is the final stage.

\section{CONCLUSION}

According to data analysis of the content for this study and designing learning environment based on ISTE standards, the following conclusions were reached: 
1. Using e- learning environments in teaching instructional technology course.

2. Adopting the ISTE standards in designing learning environments.

3. The ISTE Standards support educators, students with clear guidelines for the skills and knowledge necessary.

\section{Recommendations}

In the light of results of the study, the following recommendations are offered:

1. Hold training courses for students and teachers in universities to introduce ISTE standards, and motivate teachers and students to embrace these standards.

2. Integrate ISTE standards in academic preparation programs for teachers of faculty of education.

3. Enhance teachers' awareness of the importance of utilizing digital tools and virtual learning environments in teaching.

4. Study the implementation of ISTE standards in academic programs, schools and universities in general. 


\section{REFERENCES}

Crompton, H. (2014). Know the ISTE Standards for Teachers: Keep learning and leading. Professional learning article. https://www.iste.org/explore/articleDetail?articleid=172

O’Neil, H. F., \& Perez, R. S. (2013). Web-Based Learning: Theory, Research, and Practice. Lawrence Erlbaum Associates. doi:10.4324/9780203759820

Kruse, K. (2002). Introduction to Instructional Design and the ADDIE Model. Retrieved January, 2002 from docshare01.docshare.tips

Davis, A. L. (2013). Using instructional design principles to develop effective information literacy instruction: The ADDIE model. Association of College \& Research Libraries, 74(4). https://crln.acrl.org/index.php/crlnews/ article/view/8934/9656

Molenda, M. (2003). In Search of the Elusive ADDIE Model. Performance Improvement, 42(5), 34-37. doi:10.1002/pfi.4930420508

Morrison, G. R. (2010). Designing Effective Instruction (6th ed.). John Wiley \& Sons.

Beetham, H., \& Sharpe, R. (2013). Rethinking Pedagogy for a Digital Age: Designing for 21st Century Learning (2nd ed.) Academic Press.

Moehring, J. (2012). The 21st Century Learning Environment: Education in the Digital Era (Master thesis). University of Washington.

21. st Century Learning Environments. (2007). Partnership for $21^{\text {st }}$ Century Skills. https://ar.scribd.com/ document/259876302/21st-Century-Skills-Curriculum-and-Instruction-Learning-Environment

Glossary of Education Reform. (2013). https://edglossary.org/learning-environment/

Magdy S. Aqle (PhD) holds a PhD degree in Instructional technology-eLearning from Ein Shams university, Egypt, it was a scholarship from UNISECO. He is working as associated Prof. at the faculty of education at the Islamic University of Gaza. He also the head of practical education, also he was the head of instructional tech. center, he is the deputy dean of education journal. Dr. Magdy also worked as computer teacher at UNRWA and MOE -Palestine from 2006-2008. He is interested in eLearning, Augmented Reality in education, Virtual learning environment, flipped classroom and adaptive learning. Dr. Magdy has many research in instructional tech. field and eLearning. 